\title{
Віддалені наслідки пасивного куріння батьків на морфофункціональний стан тимуса в їхніх нащадків
}

\author{
Вікторія Ткаченко ${ }^{1}$, Тетяна Комісова ${ }^{2}$ \\ ${ }^{1}$ Харківська спеціалізована школа I-III ступенів №134, Харків, Україна \\ ${ }^{2}$ Харківський національний педагогічний університет імені Г. С. Сковороди, Харків, Україна \\ Адреса для листування: annetka1999@ukr.net
}

Отримано: 22.04.19; прийнято до друку: 20.05.19; опубліковано: 28.06.19

\begin{abstract}
Резюме. У дослідженні показано, що зміни в морфофункціональному стані тимуса в нащадків-щурів, виношених в умовах батьківського тютюнокуріння, проявляються залежно від обкурювання лише батька або батька й матері, а також від терміну зробленого надрізу шкіри. Мета дослідження - вивчити морфофункціональний стан тимуса нащадків, виношених в умовах батьківського куріння, яким нанесено механічну рану. Тварини підлягали інтоксикації тютюновим димом від цигарок «Ватра» без фільтру 3 умістом 0,8 мг нікотину та 15 мг смоли. Двомісячних нащадків із механічною раною на зовнішній поверхні правої задньої кінцівки, батьки яких підлягали пасивному курінню, виводили 3 експерименту через 24 і 48 год після зробленого надрізу. Виявлено збільшення абсолютної маси тимуса на $54 \%$ $(\mathrm{p} \leq 0,01)$ у щуренят групи ВБ24, де обкурювався лише самець-«батько», а в нащадків групи ВМБ24, де обкурювалися самець-«батько» й самиця-«мати» - на 52 \% (p $\leq 0,01)$. Відносна маса тимуса в нащадків цих груп збільшується на $15 \%$ ( $\leq 0,01)$. Установлено збільшення площі ядер епітеліоцитів тимуса на $14 \%(\mathrm{p} \leq 0,01)$ у нащадків групи ВМБ24. Показано, що в мозковій речовині тимуса нащадків групи ВБ48 спостерігаємо проліферацію епітеліальних клітин. Мозкова речовина тимуса нащадків групи ВМБ48 характеризувалася зменшенням епітеліальних клітин та ознаками апоптозу. Виявлені зміни $\epsilon$ специфічними проявами стресорної відповіді на загоєння ран у нащадків, батьки яких підлягали хронічному обкурюванню.
\end{abstract}

Ключові слова: резистентність, механічна рана, пасивне тютюнокуріння, тимус, епітеліоцити.

\section{Long Term Effects of Passive Smoking Parents on the Morpho- Functional State of Thymus of Their Offsprings}

\section{Victoria Tkachenko, Tetiana Komisova}

Kharkiv Specialized School of I-III degrees №134, Kharkiv, Ukraine Skovoroda Kharkiv National Pedagogical University, Kharkiv, Ukraine Correspondence: annetka1999@ukr.net

\footnotetext{
Abstract. The study shows that changes in the morphofunctional state of thymus of the offsprings of rats, taken in conditions of parental tobacco smoking, are manifested depending on the smoking of only the father or father and mother, as well as on the period of the skin cut was made. The animals were subjected to intoxication with tobacco smoke from cigarettes «Vatra» without a filter containing $0,8 \mathrm{mg}$ of nicotine and $15 \mathrm{mg}$ of tar. The presence in the blood of parent-rat main metabolite Nicotine - Quinine $(8,22 \pm 0,57 \mu \mathrm{g} / \mathrm{L}, \mathrm{P} \leq 0,05)$ is an indisputable proof of the fact of passive tobacco intoxication. To investigate the resistance of descendants born in conditions of parental smoking, the morphofunctional state of the thymus was studied in healing wounds. For this purpose, for the infant rats of the studied groups, at the age of 2 months, mechanical cuts with the length of $10 \mathrm{~mm}$, width $3 \mathrm{~mm}$ on the outer surface of the right hind limb within one day were made. The two-months offsprings whose parents were subjected to passive smoking were withdrawn from the experiment after 24 hours (WB24, VMB24) and 48 hours after the incision (groups B48, VMB48). It was found that the most significant 
changes in the morphohistological structure of the thymus (increase in absolute and relative body mass, increase in the area of nuclei of epitheliocytes) occurred in the descendants, whose passive smoking was subjected both to the father and mother (VMB24). An increase in the absolute thymus mass by $54 \%(\mathrm{p} \leq 0,01)$ was found in the group of WB24 rats, where only the male «father» was smoked, and the descendants of the group VMB24, where the male-father and the female-mother were smoked on $52 \%(\mathrm{p} \leq 0,01)$. Relative mass of thymus of the descendants of these groups increases to $15 \%(\mathrm{p} \leq 0,01)$. A $14 \%$ increase in the area of nuclei of epithelial cells of thymus of the descendants of the group VMB24 has been found to $(p \leq 0,01)$. It has been shown that proliferation of epithelial cells is observed in the brain substance of the thymus of the descendants of the group WB48 on the 48th hour after mechanical wounding. The brain substance of the thymus of the descendants of the VMB48 group on the $48^{\text {th }}$ hour after mechanical wound infliction was characterized by a decrease in epithelial cells and signs of apoptosis. The revealed changes are specific manifestations of the stress response to healing wounds of descendants whose parents were subjected to chronic passive smoking.

Key words: resistance, mechanical wound, passive tobacco smoking, thymus, epithelial cells.

\section{Ветуп}

За останнє десятиріччя імунна система дітей перебуває в центрі уваги дослідників. Це пов'язано зі зростанням захворювань дітей, батьки яких підлягають хронічним стресам. До стресових факторів можна віднести не лише емоційні переживання, а й шкідливі звички (тютюнокуріння, уживання алкогольних напоїв, тощо). Клінічні та експериментальні дослідження довели, що тютюнокуріння, у т. ч. й пасивне, $\epsilon$ фактором ризику понад 20 хвороб [1], більшість яких у курців протікає важче, ніж у людей, які не палять, що може свідчити про зниження в них імунітету. Тимус $є$ одним із найважливіших імунокомпетентних органів. У літературі наявні дані, що під впливом стресових чинників, таких як гіпокінезія, тривалий емоційний стрес, фізичні й гравітаційні перенавантаження, у вживання алкоголю тощо, відбуваються морфофункціональні зміни тимуса. Так, у дослідженнях Г. А. Мороз [2] зазначається про виявлені гемодинамічні порушення та ознаки акцидентальної інволюції тимуса щурів, які піддавалися систематичним гравітаційним перенавантаженням. Стресорна дія численних перенавантажень викликає швидку інволюцію органа. Порушення мікроциркуляції на фоні гіперплазії ендотеліальних клітин i розростання в судинних стінках сполучної тканини викликає гіпоксію паренхіми, що, зі свого боку, потенціює дистрофічні процеси лімфоцитарного й епітеліального компонентів тимуса. Такі зміни характерні для хронічного стресу. Аналогічні зміни тимуса під час холодового стресу спостерігала О. В. Маткіна [3], У тимусі нащадків щурів, отриманих від самок, які тривалий час вживали $15 \%$ розчин етанолу, відзначаються специфічні патоморфологічні зміни: некрози, крововиливи, лімфоїдні вузлики [4].

Проте на сьогодні залишається відкритим питання пливу куріння батьків на імунокомпетентні органи нащадків, зокрема на тимус.
Мета дослідження - вивчити морфофункціональний стан тимуса нащадків, виношених в умовах батьківського куріння, яким нанесена механічна рана.

\section{Матеріали й методи}

Дослідження проводили на 137 щурах (40 самиць-матерів, 15 самців-батьків, 82 нащадків-самиць віком два місяці) лінії Вістар. Тварин утримували в стандартних умовах віварію при природному освітленні, на загальноприйнятому раціоні. Уживання води вільне.

Усі досліди здійснювали відповідно до законодавства України [5], правил Європейської конвенції щодо захисту хребетних тварин, котрі використовують в експериментальних дослідженнях та 3 іншою науковою метою [6].

Самці-батьки та самиці-матері підлягали інтоксикації тютюновим димом від цигарок «Ватра» без фільтру з умістом 0,8 мг нікотину й 15 мг смоли.

Для дослідження резистентності нащадків, виношених в умовах батьківського куріння, вивчали морфофункціональний стан тимуса під час загоювання ран. Із цією метою щуренятам досліджуваних груп віком 2 місяці впродовж одного дня зроблено механічні надрізи довжиною 10 мм, шириною 3 мм на зовнішній поверхні правої задньої кінцівки.

Моделювання хронічного пасивного тютюнокуріння здійснено за допомогою сконструйованої герметичної камери розміром 27 л. (Пріоритетна справка № 3991837 від 13.12 .1985 р. Держкомвинахід [7]. Цей об’єм повітря закритої камери є достатнім для п'ять щурів, у якому вони можуть вільно перебувати без зовнішніх проявів гіпоксії. Тютюновий дим $1 / 2$ цигарки дозовано подавався до камери. У камері під час обкурювання одночасно було п'ять тварин упродовдж 15 хв $(5$ хв на нагнітання диму в камеру й 10 хв - на спостереження за поведінкою тварин). Під час перших 2-3 обкурювань тварини перебували в 
Віддалені наслідки пасивного куріння батьків на морфофункиіональний стан тимуса в їхніх нащадків камері 10 хв. Обкурювання проводилося 1 раз на добу. Усього проведено 51 обкурювання. Експеримент тривав 5 місяців. Тварини контрольної групи утримувалися впродовж 15 хв у тій самій камері, але не підлягали дії тютюнового диму. Під час спарювання обкурювання під дослід-них тварин не проводили.

Для встановлення ступеня інтоксикації щурів тютюновим димом визначали кількість головного метаболіту нікотину в сироватці крові - тіоцианіду К (котиніну) спектрофотометричним методом $[8,9, \quad 10]$. Дослідження сироватки крові щурів-батьків проводили в лабораторії біохімії Центральної науково-дослідної лабораторії Харківського національного медичного університету.

Виведення 3 експерименту контрольних i піддослідних тварин здійснювали відповідно до умов евтаназії, згідно з методичними рекомендаціями МО3 України та загальних етичних принципів проведення експериментів на тваринах, узгоджених із положеннями «Європейської конвенції про захист хребетних тварин, які використовуються для дослідних та інших наукових цілей» [6]. Евтаназію тварин проводили внутрішньочеревним уведенням трьохкратної наркотичної дози етаміналу-натрію.

Двомісячних нащадків, батьки яких підлягали пасивному курінню, виводили 3 експерименту через 24 та 48 год після зробленого надрізу (механічна рана). Щуренят iз механічною раною розподілили на групи: К24, К48 - нащадки контрольних групи (батьки не підлягали пасивному курінню); ВБ24, ВБ48 - нащадки експериментальних груп, де пасивному курінню підлягав лише батькосамець від цигарок «Ватра» без фільтру. В експериментальних групах ВМБ24, ВМБ48 пасивному курінню від цигарок «Ватра» без фільтру підлягали i батько-самець, i матисамиця. Для аналізу отриманих даних використовували референтні значення досліджуваних показників кафедри анатомії та фізіології людини та тварин імені професора Я. Р. Синельникова Харківського національного педагогічного університету імені Г. С. Сковороди.

Після декапітації в нащадків узято тимус для морфофункціонального дослідження. Масу тіла щурів контролювали за допомогою зважування тварин на настільних циферблатних вагах ВНЦ-2М (погрішність: $\pm 2 г$ ). Абсолютну масу тимуса визначали зважуванням на аналітичних електронних вагах AXIS AN50 (ціна ділення 0,0001 г). Відносну масу тимуса розраховували за відношенням до маси тіла тварини.

Для гістологічних досліджень тимус фіксували в 10 \%-вому нейтральному формаліні, збезводнювали в спиртах висхідної концентрації та заливали в парафінові блоки. Зрізи товщиною 5-6 мкм забарвлювали гематоксиліном-еозином. Світлову мікроскопію проводили на мікроскопі Zeiss (Німеччина). Морфометрію тимуса щурят проводили, використовуючи мікроскоп «Біолам» (Російська Федерація) при збільшенні х400. Мікрофотографування здійснювали на мікроскопі «Olympus» (Японія).

Проводили комп'ютерну каріометрію епітеліоцитів тимуса на цифрових зображеннях за допомогою програми, придатної до мікроскопа «Olympus» (Японія). У кожному препараті методом випадкової вибірки оцінювали 10 полів зору. В обраних вибірках досліджували по 30 ядер.

Вірогідність відмінностей оцінювали за допомогою критерія t-Стьюдента при $\mathrm{p} \leq 0,05$. Цифровий матеріал обробляли стандартними методами варіаційної статистики [11].

\section{Результати та їх обговорення}

Для встановлення хронічної тютюнової інтоксикації в батьків-щурів у крові визначали вміст головного метаболіту нікотину котиніну $[8,9,10]$.

Незаперечним доказом факту пасивної тютюнової інтоксикації є статистично значиме збільшення котиніну $(8,22 \pm 0,57$ мкг/л, $\mathrm{p} \leq 0,05)$ у тварин, що підлягали обкурюванню цигарками «Ватра» без фільтру, порівняно з контрольною групою (6,34 $\pm 0,32$ мкг/л).

Під час вивчення абсолютної та відносної маси тимуса в щуренят, батьки яких обкурювалися цигарками «Ватра» без фільтру, показано що вона статистично значимо збільшується в нащадків лише на 24 год після нанесення механічної рани. У щуренят групи (ВБ24), де обкурювався лише самець-«батько», абсолютна маса тимуса збільшується на $54 \%$ ( $\mathrm{p} \leq 0,01)$, а в нащадків групи, де обкурювалися самець-«батько» та самиця-«мати» (ВМБ24) на $52 \%(\mathrm{p} \leq 0,01)$. Відносна маса тимуса в нащадків цих груп збільшується на $15 \%$ $(\mathrm{p} \leq 0,01)$ (табл. 1). На 48 год після нанесення механічної рани в нащадків груп ВБ48 та ВМБ48, порівняно 3 контрольними та референтними значеннями, вірогідної різниці в масі тимуса не виявлено (табл. 1).

У попередніх дослідженнях відзначено розбіжні дані щодо впливу стресових факторів на масу тимуса. Так, про збільшення маси тимуса в піддослідних тварин, які підлягали стресу, свідчать дослідження І. В. Городецької та ін. [12] Однак, за даними досліджень 
Науковий вісник Східноєвропейського національного університету імені Лесі Українки. Серія: Біологічні науки, 2019, 3 (387)

D. Zeyrek, E. Ozturk, A. Ozturk, A. Carmak [13], куріння матері істотно впливає на зменшення ваги тимуса ऑii нащадків. Під впливом емоційного, транспортного та низькотемпературного стресу маса тимуса в піддослідних тварин і птахів також зменшується $[14,15]$.

У процесі дозрівання клітин тимуса (тимоцитів) важливу роль відіграють епітеліоцити [16].
У нашому дослідженні на гістологічних зрізах мозкової речовини тимуса нащадків контрольної групи (К48) на 48 год спостереження за загоюванням механічної рани простежено велику кількість макрофагів й активацію епітеліоцитів (рис.1).

Площа ядер епітеліоцитів тимуса статистично значуще збільшується на $14 \%$ $(\mathrm{p} \leq 0,01)$ у нащадків лише в групі ВМБ24,

Таблиия 1

Абсолютна маса тимуса, 2 , відносна маса тимуса, 2 та площа ядер епітеліоцитів тимуса, мкм² нащадків, батьки яких підлягали обкурюванню цигарками «Ватра» без фільтру

\begin{tabular}{|c|c|c|c|c|c|c|c|}
\hline Група & $\begin{array}{c}\text { Референтн } \\
\text { і значення }\end{array}$ & $\begin{array}{c}\text { К24 } \\
(\mathbf{n} 5)\end{array}$ & $\begin{array}{c}\text { ВБ24 } \\
\text { (n 10) }\end{array}$ & $\begin{array}{c}\text { ВМБ24 } \\
\text { (n 10) }\end{array}$ & $\begin{array}{c}\text { K48 } \\
\text { (n 5) }\end{array}$ & $\begin{array}{c}\text { ВБ48 } \\
\text { (n 9) }\end{array}$ & $\begin{array}{c}\text { BМБ48 } \\
\text { (n 15) }\end{array}$ \\
\hline $\begin{array}{c}\text { Абсолютна } \\
\text { маса тимуса }\end{array}$ & $0,11 \pm 0,01$ & $0,12 \pm 0,01$ & $0,26 \pm 0,03, *$ & $0,25 \pm 0,03, *$ & $0,22 \pm 0,02$ & $0,20 \pm 0,03$ & $0,27 \pm 0,02$ \\
\hline $\begin{array}{c}\text { Відносна } \\
\text { маса } \\
\text { тимуса }\end{array}$ & $0,002 \pm 0,001$ & $0,002 \pm 0,001$ & $0,003 \pm 0,001, *$ & $0,003 \pm 0,001, *$ & $0,002 \pm 0,001$ & $0,002 \pm 0,001$ & $0,002 \pm 0,001$ \\
\hline \begin{tabular}{c} 
Площа ядра \\
\hline
\end{tabular} & $11,73 \pm 0,22$ & $11,16 \pm 0,18$ & $11,06 \pm 0,49$ & $13,01 \pm 0,76, *$ & $10,02 \pm 0,01$ & $12,98 \pm 0,87$ & $11,18 \pm 0,37$ \\
\hline
\end{tabular}

Примітка. $n$ - кількість нащадків; *-вірогідність різниці, порівняно з контрольною групою К24, при $p \leq 0,01$.

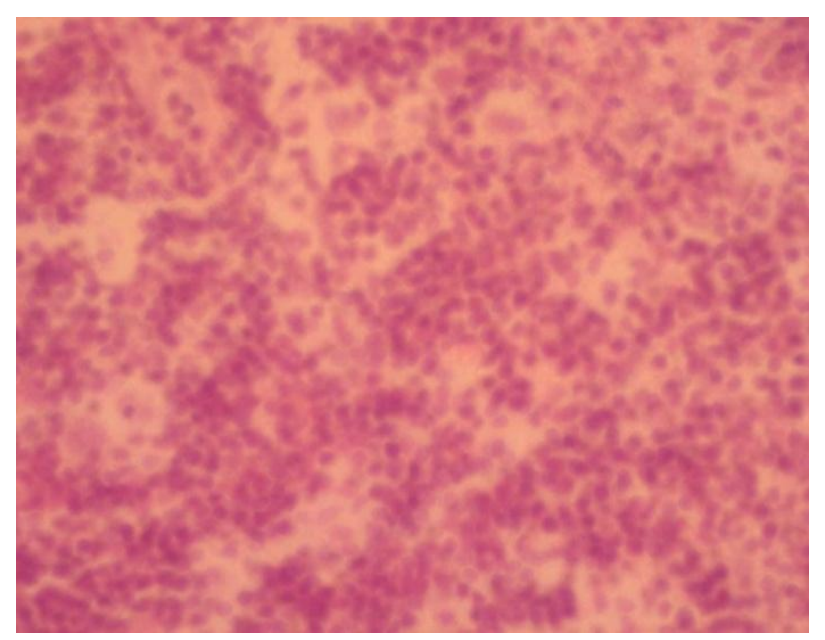

Рис.1. Мозкова речовина тимуса контрольної тварини через 48 год після нанесення механічного лінійного пошкодження шкіри. Велика кількість макрофагів й активація епітеліоцитів. Забарвлення гематоксиліном-еозином. Збільшення х 400

порівняно 3 контрольними (К24) i референтними значеннями (табл. 1).

У нащадків групи, де хронічній тютюновій інтоксикації підлягав лише самець-«батько»
(ВБ24), на 24 год після нанесення механічної рани площа ядер достовірно не змінювалася. У мозковій речовині тимуса нащадків групи, де хронічній тютюновій інтоксикації підлягав лише самець-«батько» (ВБ48), на 48 год після

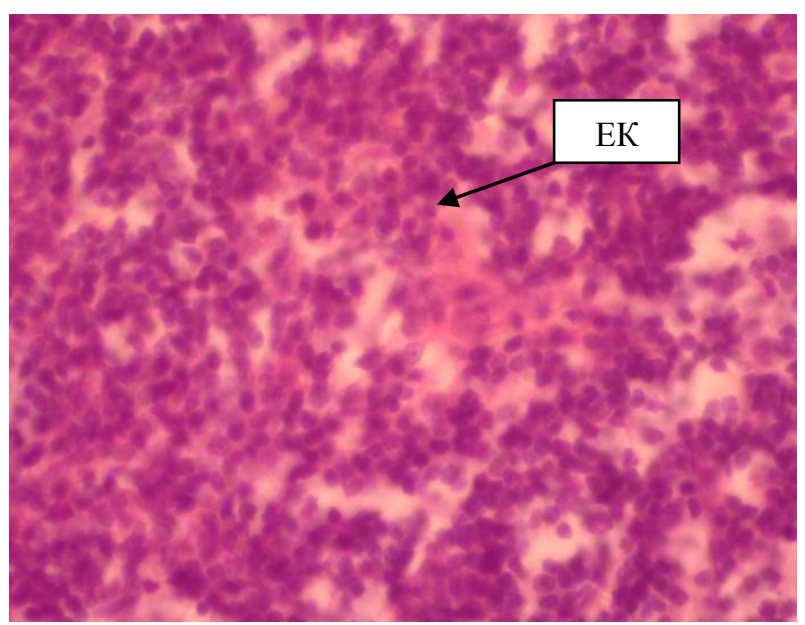

Рис. 2. Мозкова речовина тимуса тварини групи ВБ48 через 48 год після нанесення механічного лінійного пошкодження шкіри. Проліферація епітеліальних клітин (EK). Забарвлення гематоксиліном-еозином. Збільшення х 400 
Віддалені наслідки пасивного куріння батьків на морфофункиіональний стан тимуса в їхніх нащадків нанесення механічної рани спостерігається проліферація епітеліальних клітин (рис. 2).

Площа ядер епітеліоцитів у нащадків цієї групи статистично значимо не змінювалася (табл. 1).

Мозкова речовина тимуса нащадків групи, де обкурювались і самець-«батько», і самиця«мати» (ВМБ48), на 48 год після нанесення механічної рани характеризувалася зменшенням епітеліальних клітин та ознаками апоптозу (рис. 3).

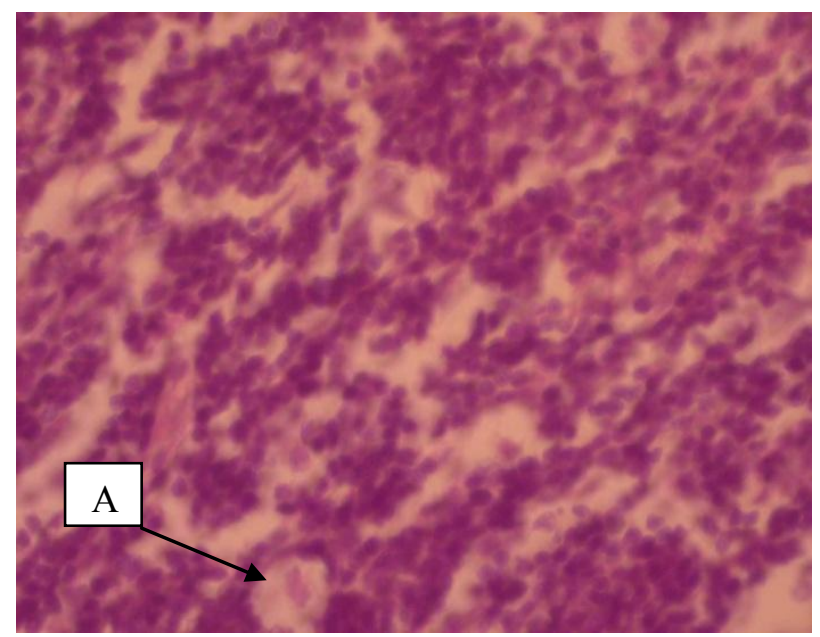

Рис. 3. Мозкова речовина тимуса тварини групи ВМБ48 через 48 год після нанесення механічного лінійного пошкодження шкіри.

Поява пустот у мозковій речовині, зменшення епітеліальних клітин та ознаки апоптозу (A).

Забарвлення гематоксиліном-еозином. Збільшення $x 400$

Площа ядер епітеліоцитів мозкової речовини тимуса нащадків цієї групи (ВМБ48) вірогідно не відрізнялася від контрольних та референтних показників (табл. 1).

\section{Висновки}

Виявлене збільшення відносної маси тимуса та збільшення площі ядер епітеліоцитів у групі ВМБ24 спричиняє специфічні прояви стресорної відповіді на загоєння ран у нащадків, батьки яких підлягали хронічному обкурюванню. Проте відзначимо, що інволютивних процесів у тимусі не виявлено, що підтверджувалося збільшенням відносної маси органа.

Установлено, що найбільші морфофункціональні зміни тимуса відбулись у щуренят на 24 год після нанесення механічної рани в групах, де хронічній тютюновій інтоксикації підлягав самець (ВБ24) і самець та самиця (ВМБ24). В останній групі простежимо також збільшення площі ядер епітеліоцитів.

У подальшому планується вивчення адаптаційних змін надниркових залоз у нащадків-щуренят, батьки яких підлягали пасивному курінню.

\section{Література}

1. World Health Organization. WHO Report on the Global Tobacco Epidemic, 2008: The MPOWER Package. Geneva, Switzerland: World Health Organization; 2008

2. Мороз, Г. О. Динаміка відносної маси наднирнокових залоз, тимуса і селезінки щурів під впливом гіпергравітації. Морфологія; 2009, Т. 3, № 2, c 42-46.

3. Маткина, О. В. Патологические изменения в тимусе и селезенке неинбредных белых крыс при оостром стрессе. Пермский медииынский журнал, T. 31, №1, 2014, с 121-128.

4. Пугач, П. В., Круглов, С. В. и др. Строение тимуса и брыжеечных лимфатических узлов новорожденных крыс в результате антенатального влияния этанола. Педиатр; 2015, Т. 6, № 4, с 51-55. DOI: $10.17816 /$ PED6451-55

5. Закон України №3447-IV «Про захист тварин від жорстокого поводження». Відомості Верховної Ради України; 2006, № 27, с 230.

6. European convention for the protection of vertebrate animals used for experimental and other scientific purposes. Council of Europe: Strasbourg, $1986.53 \mathrm{p}$.

7. Гарбузова, С. Н. Лимбико-неокортикальные механизмы формирования зависимости от курения (экспериментальное исследование). Автореф. дис. на здобуття наук. ступеня канд. біол. наук: спец. 03.00.13. «Фізіологія тварин та людини», Харьков, 1986, $17 \mathrm{c}$.

8. Benowitz. N. L, Hukkanen, J, Jacob. P3rd. Nicotine chemistry, metabolism, kinetics and biomarkers. Handb Exp Pharmacol; 2009, 192, p 29-60.

9. Goniewicz, M. L, Eisner. M. D, LazcanoPonce. E, Zielinska-Danch. W, Koszowski, B, Sobczak, A, Havel, C, Jacob, P, Benowitz, N. L. Comparison of urine cotinine and the tobacco-specifi c nitrosamine metabolite 4-(methylnitrosamino)-1-(3-pyridyl)-1butanol (NNAL) and their ratio to discriminate active from passive smoking. Nicotine Tob Res, 2011, 13(3), p 202-8.

10. Беляев, С. Г. Модифицированный способ определения тиоцианидных ионов в слюне и моче. Проблемы современной медицинской науки и образования, № 1, 2009, с 88-90.

11. Антроментова, Л. О., Утевська, О. М. Біометрія. Порівняння груп і аналізу зв'язку; Харків; Ранок: 2007, 196 c.

12. Городецька, І. В., Кореневська. Н. А. Вплив тиреоїдного статусу на інтенсивність стрес-реакції при хронічному стресовому впливі. Вісник Вітебського державного медичного університету, Т. 9, № 4, 2010, с 24-33. 
Науковий вісник Східноєвропейського національного університету імені Лесі Українки. Серія: Біологічні науки, 2019, 3 (387)

13. Zeyrek, D., Ozturk, E., Ozturk, A., Carmak, A. Pescreased thymus size in full-term newborn infahtsof smoking mothers. Med Sci Monit; 2008, Aug; 14/8.

14. Турицына, Е. Г. Иммунодефициты птиц: этиология, патогенез, морфологическая диагностика, и способы коррекции: монография, Краснояр. гос. аграр. ун-т. 2-е изд., доп. и перераб., Красноярск, 2012, 283 с

15. Майоров, О. Ю. Количественная оценка состояния «нейроэндокринных осей» и имунной системы в условиях экспериментального эмоционального сресса: факторная модель. Клиническая информатика и Телемедицина; Т.11, вып.12, 2015, с 31-42.

16. Торбек, В. Е., Юріна, Н. А. Ультрастуктура епітеліоцитів тимуса нащадків при зміні гормонального фону у функціональній системі мати-плід. Вісник РУДН. Серія медицина; № 2, 2002. c $45-49$ 